\title{
Acute renal failure following oxalic acid poisoning: a case report
}

\author{
Uditha Dassanayake and Christeine Ariaranee Gnanathasan*
}

\begin{abstract}
Oxalic acid poisoning is being recognized as an emerging epidemic in the rural communities of Sri Lanka as it is a component of locally produced household laundry detergents. Herein we describe a case of a 32 year old female, presenting after direct ingestion of oxalic acid. She then went on to develop significant metabolic acidosis and acute renal failure, requiring dialysis. Renal biopsy revealed acute tubulointerstitial nephritis associated with diffuse moderate acute tubular damage with refractile crystals in some of the tubules. The patient symptomatically improved with haemodialysis and renal functions subsequently returned to normal.
\end{abstract}

Keywords: Oxalic acid poisoning, Acute renal failure, Sri Lanka

\section{Background}

Oxalic acid is a toxic organic compound, commonly used as a reducing agent in photography, bleaching and dust removal, as well as being found in certain plants and natural sources. Oxalic acid as a toxin is mostly described in the context of ethylene glycol poisoning, as it is a metabolite of ethylene glycol. Other reported cases of isolated oxalic acid poisoning involve the consumption of food, medications and plants that contain the compound, for example, star fruit and ascorbic acid [1]. Human reports of toxicological effects are relatively uncommon but include gastrointestinal effects, hypocalcemia secondary to calcium oxalate crystal formation and renal toxicity.

Although it is not common in most part of the world, direct intoxication with oxalic acid is a relatively frequent occurrence in some parts of Sri Lanka [2], due to it being a major component of some household laundry detergents. Here we report a case of a patient who went on to develop acute renal failure following self ingestion, and the sequence of events following the event in the local healthcare setting.

\section{Case Presentation}

The patient, a 32 year old female, had ingested approximately $12.5 \mathrm{~g}$ of $70 \%$ oxalic acid mixed in a glass of

\footnotetext{
* Correspondence: ariaranee2000@yahoo.com

Department of Clinical Medicine, Faculty of Medicine, University of Colombo, Colombo, Sri Lanka
}

(c) 2012 Dassanayake and Gnanathasan; licensee BioMed Central Ltd. This is an Open Access article distributed under the terms

water in an attempt at deliberate self harm. Immediately after ingestion, she experienced abdominal pain and profuse vomiting and was brought to the local rural hospital within 2 hours of ingestion. After intravenous access was established and an initial assessment was done, she was immediately transferred to the regional hospital. On arrival, 4 hours after ingestion, she was found to be drowsy but alert (Glasgow coma scale 15), but with a pulse rate (PR) of $50 / \mathrm{min}$ and a blood pressure (BP) of $80 /$ $60 \mathrm{mmHg}$. Oxygen saturation on air $\left(\mathrm{SpO}_{2}\right)$ was $92 \%$. Immediate volume resuscitation was done and the patient required inotropic support during the first 24 hours. Vomiting continued throughout the day, with two episodes of blood stained vomitus.

Her urine output was maintained subsequently, but by the $3^{\text {rd }}$ day she developed worsening generalized oedema with a reduction of urine output to approximately $20 \mathrm{ml} / \mathrm{hr}$. There was gradual elevation of serum creatinine (S.Cr) levels (up to $704 \mathrm{umol} / \mathrm{dl}$ ) and blood urea (BU) levels (up to $43.5 \mathrm{mmol} / \mathrm{dl}$ ). She was transferred to our hospital on the $3^{\text {rd }}$ day after oxalic acid ingestion. On admission, she was febrile (temperature $99.6^{\circ} \mathrm{C}$ ), nauseous, with stable vital parameters (PR $82 / \mathrm{min}$, BP $120 / 80 \mathrm{mmHg}, \mathrm{SpO}_{2} 99 \%$ on air) and mild tachypnoea. There was generalized oedema with bilateral fine basal crepitations in the lungs. S.Cr level was $493 \mathrm{umol} / \mathrm{dl}$, with serum potassium $\left(\mathrm{S} . \mathrm{K}^{+}\right)$of $4.8 \mathrm{mEq} / \mathrm{l}$ and a white blood cell (WBC) count of 22,500/ul with $87 \%$ neutrophils. Urinalysis revealed active sediment (70-80 red 
cells, 1-2 pus cells/hpf). Arterial blood gases (ABG) showed a metabolic acidosis, with a $\mathrm{pH}$ of $7.328, \mathrm{PaCO}_{2}$ of $33.2 \mathrm{mmHg}, \mathrm{PaO}_{2}$ of $84.2 \mathrm{mmHg}, \mathrm{BE}$ of -6.2 and a $\mathrm{HCO}_{3}$ of $18.9 \mathrm{mmol} / \mathrm{L}$.

The patient underwent hemodialysis on the $3^{\text {rd }}$ day, with symptomatic improvement. Post dialysis ABG revealed a respiratory alkalosis $\left(\mathrm{pH}\right.$ of $7.479, \mathrm{PaCO}_{2}$ of $34.9 \mathrm{mmHg}, \mathrm{PaO}_{2}$ of $91.9 \mathrm{mmHg}, \mathrm{BE}$ of 2.5 and a $\mathrm{HCO}_{3}$ of $26.2 \mathrm{mmol} / \mathrm{L}$ ). The urine output remained low and she required a second dialysis on the $7^{\text {th }}$ day. Urine output increased by day 9, but the S.Cr level remained high.

Renal biopsy was performed on the $8^{\text {th }}$ day revealed acute tubulointerstitial nephritis associated with diffuse moderate acute tubular damage with refractile crystals seen in some tubules (Figure 1). This was reported as being consistent with oxalic acid poisoning. After day 9, the renal functions and urine output gradually improved. No further dialysis was required. She was prescribed antacids and mucoprotective agents and upper gastrointestinal symptoms settled. Blood picture was reported as mild normochromic normocytic anemia ( $\mathrm{Hb}: 9.1 \mathrm{~g} / \mathrm{dl})$ with normal WBC and platelets. She was transferred back to the local hospital on $12^{\text {th }}$ day and subsequently discharged on day 14.

On follow up (Day 28), she was asymptomatic with a normal S Cr. Level (114umol/L).

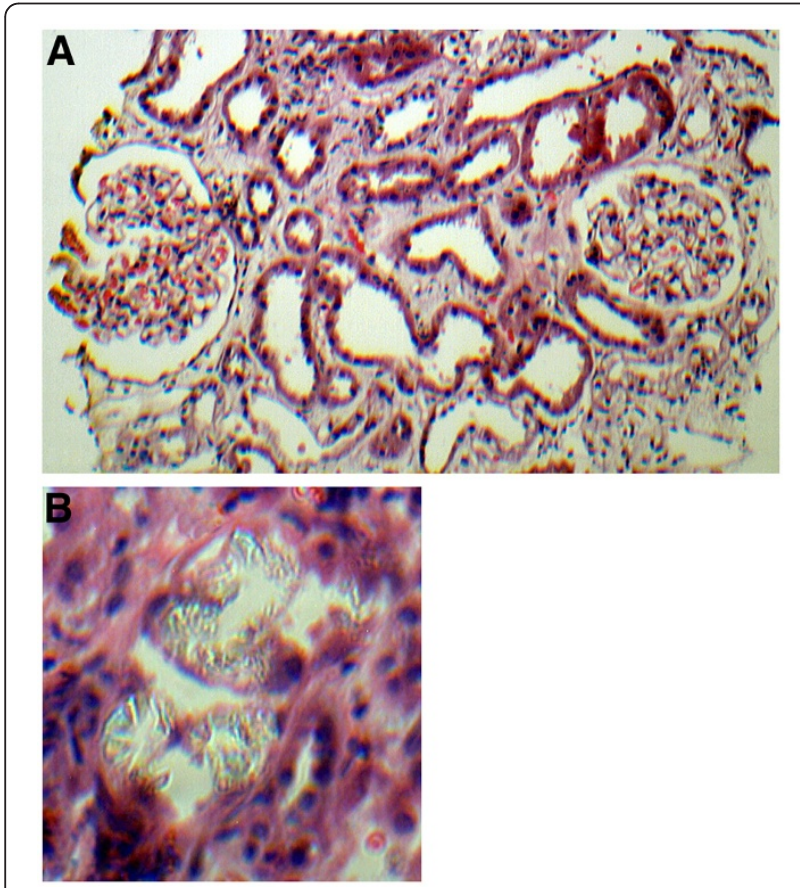

Figure 1 H \& E Staining. A Necrosis of tubular epithelial cells. Interstitium contains a moderate inflammatory infiltrate composed of neutrophils, lymphocytes and a few eosinophils. Glomeruli are histologically unremarkable. B Refractile calcium oxalate crystals within renal tubules.
The clinical course of the patient is presented in Figure 2.

\section{Discussion and conclusions}

Self poisoning is a major public health problem in rural Sri Lanka, the majority of the cases being due to ingestion of yellow oleander, paraquat and organophosphorous compounds. There is an estimated prevalence of 315 to 364 per 100,000 population per year attempting self poisoning each year $[3,4]$. In recent times, the widely used and easily available laundry detergent "Prinso" has been reported to be commonly used in self poisoning attempts, especially in the Southern regions [5]. It is marketed in two sachets, containing $1.2 \mathrm{~g}$ of Potassium permanganate ( $\mathrm{KMNO}_{4}$ ) and $12.5 \mathrm{~g}$ of oxalic acid by many small scale manufacturers and is available under several trade names. Although this case only involves the ingestion of the oxalic acid component, the usual presentation is the simultaneous ingestion of both compounds.

Oxalic acid is poorly absorbed with a bioavailability of $2-5 \%$. It is excreted unchanged in the urine. The oral lethal dose of oxalic acid for adults is $15-30 \mathrm{~g}$, although the ingestion of as little as $5 \mathrm{~g}$ has caused death [6]. It may have a direct corrosive effect on the eyes, skin, and digestive tract after contact. However, once absorbed, oxalic acid and other soluble oxalates react with calcium in the plasma to form insoluble calcium oxalate.

Precipitation of calcium oxalate in the renal system (proximal tubules of the kidney) may lead to local necrosis of the tubular epithelium, producing kidney dysfunction and electrolyte imbalance [7]. In renal tubular injury the pathophysiological factors at the cellular level are considered to be energy depletion, cell swelling, calcium influx, intracellular acidosis and enzyme activation [8]. Obstruction of the renal tubules by the crystals is also a mechanism of renal damage. The relative importance of obstruction versus tubular dysfunction is still unclear. The acute renal failure of oxalate poisoning is usually managed supportively, and only a minority of reported cases in Sri Lanka have required dialysis [1].

The renal biopsy specimen revealed associated acute tubulointerstitial nephritis. Interstitial nephritis has been described in cases of chronic hyperoxaluria $[9,10]$. In this case, the findings are probably attributable to the oxalate itself, although the patient was on the proton pump inhibitor omeprazole, a known cause of interstitial nephritis [11], due to gastrointestinal symptoms.

The neutrophil casts present in some tubules may be attributable to the inflammatory infiltrate often present in acute interstitial nephritis [12], although urinary tract infection could also have been a cause with an indwelling catheter. Urine cultures were negative. 


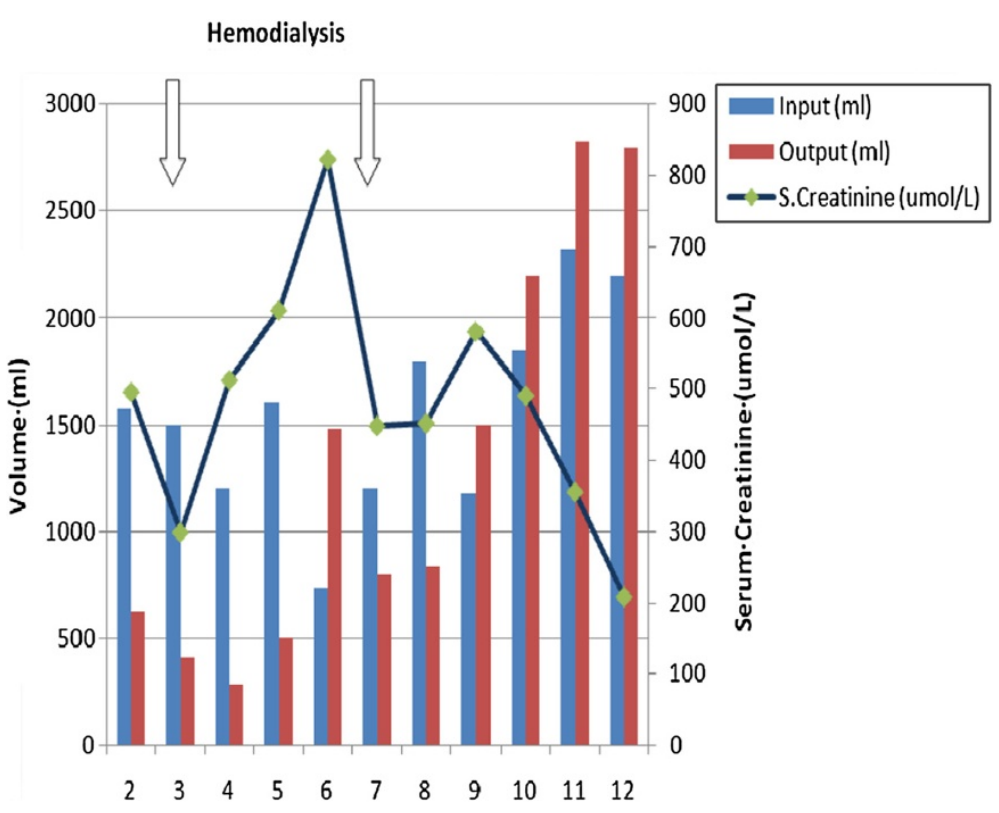

Figure 2 Clinical course - Change in urine output and serum creatinine.

Systemic formation of calcium oxalate may produce hypocalcaemia directly, although the present case had no biochemical or electrocardiographic evidence with a normal serum calcium level recorded on the $2^{\text {nd }}$ day. However, the recorded state of shock with bradycardia at presentation may have been a manifestation of hypocalcaemia, but an electrocardiograph was not available.

In ethylene glycol poisoning, oxalic acid is formed through aldehyde metabolites, and is generally assumed to be the cause of the renal failure associated with ethylene glycol poisoning [13]. The CNS and cardiopulmonary effects are speculated to be due to the aldehyde metabolites. The present case also suggests that the direct toxicity of oxalic acid involves renal failure without significant cardiopulmonary or CNS manifestations.

In conclusion, oxalic acid poisoning has been clearly linked with acute renal impairment, and hence has the potential for fatal consequences. Therefore, better regulation of household products that contain the chemical and education of the general population may be necessary to control this emerging epidemic in the local setting.

\section{Consent}

Written informed consent was obtained from the patient for publication of this Case report and any accompanying images. A copy of the written consent is available for review by the Editor-in-Chief of this journal.

\section{Author's contributions}

AG overview of patient management, writing up of the case report. UD patient management, writing up of the case report. All authors read and approved the final manuscript.

\section{Author's information}

AG : MBBS, MPhil, MD, FRCP. Professor in Medicine, Department of Clinical Medicine, Faculty of Medicine, University of Colombo. UD: MBBS. Registrar in Clinical Medicine, University Medical Unit, National Hospital, Colombo.

\section{Acknowledgements}

The Authors would like to acknowledge Doctors, Nursing staff and other staff of the University Medical Unit and Dialysis Unit, National Hospital, Colombo, for their invaluable contributions to patient management.

The patient and her family members, for their support and consent for publishing this case report.

Received: 11 July 2012 Accepted: 12 September 2012

Published: 14 September 2012

\section{References}

1. Chen CL, Fang HC, Chou KJ, Wang JS, Chung HM: Acute oxalate nephropathy after ingestion of star fruit. Am J Kidney Dis 2001, 37:418-422.

2. Gawarammana IB, Ariyananda PL, Palangasinshe C, de Silva NGL, Fernando $K$, Vidanapathirana $M$, et al: Emerging epidemic of fatal human self poisoning with a washing powder in Southern Sri Lanka: A prospective observational study. Clin Toxicol (Phila) 2009, 47(5):407-411.

3. Eddleston M, Sudarshan K, Senthilkumaran M, Reginald K, Karalliedde L, Senarathna $L$, et al: Patterns of hospital transfer for self-poisoned patients in rural Sri Lanka: implications for estimating the incidence of selfpoisoning in the developing world. Bull World Health Organ 2006, 84(4):276-282.

4. Manuel C, Gunnell DJ, van der Hoek W, Dawson A, Wijeratne IK, Konradsen F: Self-poisoning in rural Sri Lanka: small-area variations in incidence. BMC Publ Health 2008, 8:26.

5. Munasinghe M, Fernando W: The toxic laundry powder "Prinso" is gaining notoriety amongst villagers for deliberate self-poisoning in and around the Matara district. Sri Lanka Journal of Critical Care 2009, 1(1):29-30.

6. Silberhorn EM: Oxalates. In Encyclopedia of Toxicology. 2nd edition. Edited by Wexler P. New York: Elsevier Inc; 2005:320-322. 
7. Tsujihata M: Mechanism of calcium oxalate renal stone formation and renal tubular cell injury. Int J Urol 2008, 15:115-120.

8. Brady HR, Brenner BM, Lieberthal W: Acute Renal Failure. In Brenner and Rector's the Kidney. 5th edition. Edited by Brenner BM. Philadelphia: W.B. Saunders Co; 1996:1212-1222.

9. Rathi S, Kern W, Lau K: Vitamin C-induced hyperoxaluria causing reversible tubulointerstitial nephritis and chronic renal failure: a case report. J Med Case Reports 2007, 1:155.

10. Allen A, Clutterbuck E, Maidment G, Thompson E, Watts R, Pusey C: Enteric hyperoxaluria and renal failure associated with lymphangiectasia. Nephrol Dial Transplant 1997, 12:802-806.

11. Torregrosa E, Rovira RE, Calvo C, Hernández-Jaras J, Maduell F, García H: Acute interstitial nephritis associated with omeprazole therapy. Nefrologia 2004, 24:61-63.

12. Kodner CM, Kudrimoti A: Diagnosis and management of acute interstitial nephritis. Am Fam Physician 2003, 67(12):2527-2534.

13. McMartin $\mathrm{K}$ : Are calcium oxalate crystals involved in the mechanism of renal toxicity in ethylene glycol poisoning? Clin Toxicol (Phila) 2009, 47(9):859-869.

doi:10.1186/1745-6673-7-17

Cite this article as: Dassanayake and Gnanathasan: Acute renal failure following oxalic acid poisoning: a case report. Journal of Occupational Medicine and Toxicology 2012 7:17.

\section{Submit your next manuscript to BioMed Central and take full advantage of:}

- Convenient online submission

- Thorough peer review

- No space constraints or color figure charges

- Immediate publication on acceptance

- Inclusion in PubMed, CAS, Scopus and Google Scholar

- Research which is freely available for redistribution 